\title{
UNIVERSITYOF
}

FORWARD

THINKING

WESTMINSTER用

WestminsterResearch

http://www.westminster.ac.uk/westminsterresearch

Ballet and The Soviet Body

Sporton, G.

(c) Sporton, G., 2018.

The definitive, peer reviewed and edited version of this article is published in Scene, 6 (2), pp. 153-164:

https://dx.doi.org/10.1386/scene 000151

The WestminsterResearch online digital archive at the University of Westminster aims to make the research output of the University available to a wider audience. Copyright and Moral Rights remain with the authors and/or copyright owners. 


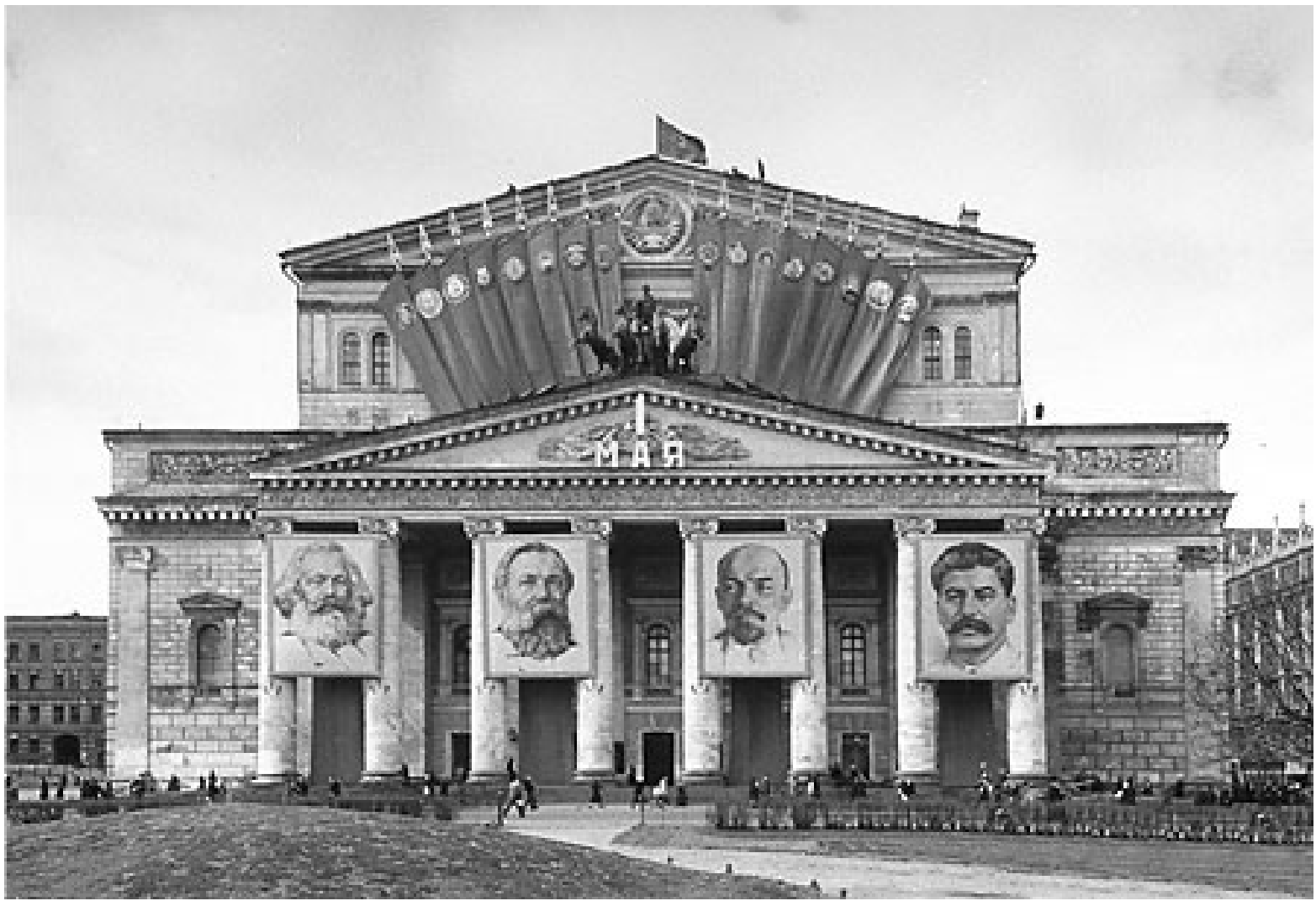

The site in the picture is the Bolshoi Theatre in Moscow. The celebration is of May Day, and this picture was taken in 1947. Already by then, the pediment of the theatre had long lost its Tsarist double-headed eagle, replaced by the Soviet coat of arms created in 1923 and affixed to the theatre not long after. ${ }^{1}$ The huge portraits of the great figures of the revolution, Marx, Engels, Lenin and Stalin, were erected for May Day celebrations and reused on the Bolshoi façade for many years, up to the end of the Soviet period. Stalin disappeared in the mid-fifties, but the others remained, staring out at the crowds in the square in front of the theatre. For the whole period of the Bolsheviks, and for many years afterwards when cranky crowds of unreconstructed communists continued the tradition, the once exclusive Bolshoi was the centre of the celebration of the Day of the Worker.

Ironies about this abound. The most striking is just how much Lenin, in particular, loathed the institution which would ultimately become the face of Soviet culture. His waspish replies to the Anatole Lunacharsky's repeated pleas for further funding for the institution once the Revolution had taken it over include an encouragement for it to survive as a going concern. The leader of the Revolution of the Proletariat thought the best thing for the Bolshoi was surviving in the marketplace. Lunacharsky's persistent support for the Bolshoi, as Commissar for Enlightenment, ultimately paid off. As vexed as Lenin was about its survival, more pressing threats to the revolution demanded his attention, and Lunacharsky got his way. It became the State Theatre, and its artistic staff proved sufficiently flexible to produce ballet for the working classes, informed as it was by Lunacharsky's own middlebrow tastes.

\footnotetext{
1 This wasn't removed until the renovation of the theatre between 2005-2011, outliving the regime itself by fifteen years or so.
} 
The survival of the Bolshoi through the turbulent politics of the time is story enough, but there is a larger tale to be told about the way ballet more generally found its way into the body politic of the Soviet Union. This aspect of its endurance is often neglected because of a preoccupation with the politics around institution building in the Soviet Union (especially its early stages). There is no doubt that in all spheres of life the USSR invented and experimented with institutional structures that would prove suitable for the new society they were seeking to build, and many of these provide evidence for us about what those fundamental values were. To balance out this account, it is worth asking questions not just about the Bolshoi, but about how ballet became synonymous with the Soviet Union beyond the overt politics of culture.

Inherent in this suggestion is a critique of foregrounding the politics and treating ballet as a symptom of it. In this essay, I will suggest it wathe subject ought to be tackled the other way around, and that ballet had a reasonable case to make as both a proletarian and Russian art, and that the founders of the Revolution and their successors were not simply pandering to the tastes of the new elite, nor seeking to protect or preserve a Tsarist legacy.

Besmirched as it was by its association with the Romanovs, there was eventually found the means of rehabilitating ballet and giving it cultural prominence. This is hard to detect without setting aside a preference for politics over art, and it is this prejudice I hope to engage.

At least partly, the interpretation of ballet as a political form stems from received wisdom about practice as symptomatic of more profound thinking. This is a difficult case to sustain from the perspective of makers of culture, who are rarely inhibited by correlating creative decisions with intellectual aims, but it is the legacy of a lens through which ballet as action is invariably assessed. Mostly, these are phenomenological accounts that grant the body a voiceless presence secondary to the interpretation of culture rather than its manifestation. This follows, I would suggest, a general assumption about dance, that the disinterested examination of it renders up something far more revealing than the passions that produce it. This often happens without acknowledging the game being played out, about how a secondary enquiry trumps a primary practice. But this in itself is insufficient for creating the wildly uneven playing field that blights enquiry into dance as a cultural form. The more pressing issue is not whether this is correct, or the right method of understanding culture, but how it is we treat it as if it were so. Ballet provides us with an excellent example how these assumptions play out, with the bodies of ballet dancers apparently mere ciphers supporting an idea rather than manifesting an end in themselves. I would suggest the enthusiasm for the quasi-science of mirror neurons is simply another way of casting the mould. ${ }^{2}$ Such accounts invariably vacillate between the voyeuristic and the vicarious and leave out the physical given its remoteness from the experience of most spectators. The more radical argument I would like to make is certainly related to the politics of the Soviet Union, but of the kind that sees a connection between the sophisticated technique required of ballet dancers and the search of a society for the means of creating meritocracy through human capital ideologically consistent with the avoidance of unearned privilege. It turns out to be no surprise that Soviet ballet was distinguished as the tough, muscular work it became. It is the reasons for this that might be in dispute.

\section{Two Lives}

In short, the example of ballet in Soviet times can demonstrate to us the alternatives to our cultural assumptions and the problems we have in the West in extending and expanding the interest in high culture forms. As I hope to explain, the technical capacity to do contains

\footnotetext{
${ }^{2}$ I have yet to see even the most battle-weary untrained balletomane replicate a step, though there is plenty of enthusiasm for the conceptual possibility that this is what fascinates us when we watch.
} 
within it a threat to the dominance of cultural capital and its ability to validate that technical capacity as high culture. This is a very critical piece of information in relation to ballet and the Soviet Union, and my argument about why ballet might possess attractive properties for a society strongly engaged in the rapid acquisition of technical and scientific processes as its national project draws on this possibility. It also contains a wider application that seeks to rebalance the relationship between artist and practice and artist and context. I will return to this proposition later, but would begin with two exemplars of contrasting lives prior to the Revolution that can help explain how ballet came to stand for the Soviet Body.

The first is Mathilde Kschessinskaya (1872-1971). She was the scantily-clad mistress to two Grand Dukes as well as Nicholas II, the possessor of a lifelong love of fine jewels and a notion about feminine beauty and how that worked on powerful men in technical terms. From a ballet dynasty, she first caught the attention of Alexander III, and made the most of her connections with the House of Romanov until her death in 1971.

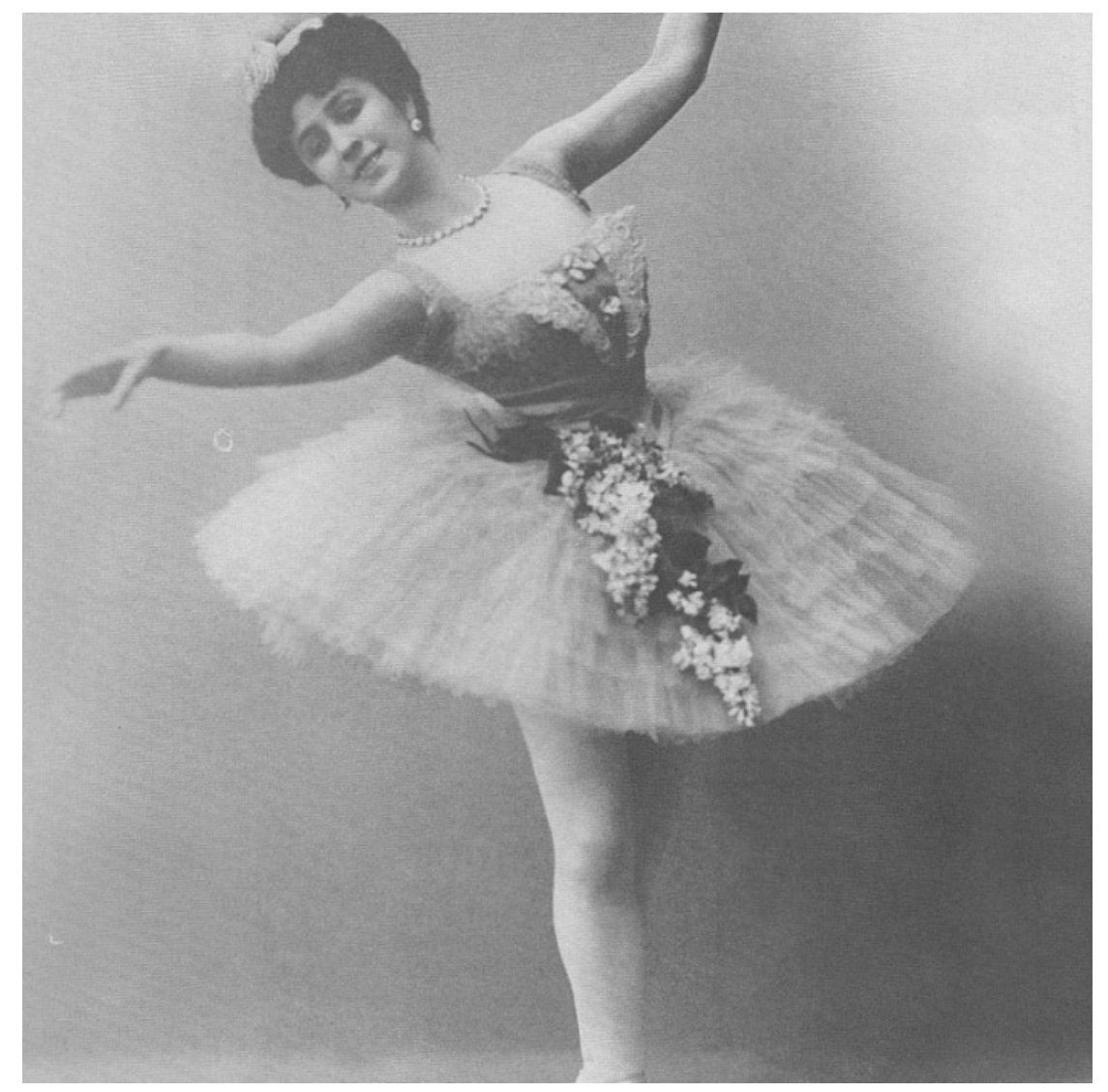

Photographs from her career in the Imperial Theatres in St. Petersburg show her in provocative poses, offering her breasts and legs, with an intuitive sense of how these formed her identity and indeed gave her power over influential men. Such was the allure she possessed that the last Tsar, Nicholas II, had a villa gifted to her, and the apocryphal stories of a secret tunnel linking it to the Winter Palace were impossible to lay to rest.

The second example is Lenin (1870-1924) himself. He was possessed of the same bourgeois taste of his education and class, his father having been principal of a well-known school in Simbirsk (where the leader of the Provisional Government that Lenin would depose, Alexander Kerensky, was a pupil) and a junior member of the table of ranks that constituted the lower end of the Russian aristocracy. He was fond of classical music, literature and film, all bookish, sedentary pursuits. He hated ballet, and took active steps to 
close the Imperial Theatres, thinking it a superfluous distraction and antediluvian in Bolshevik Russia. Apart from some occasional cycling, he rarely engaged in exercise.

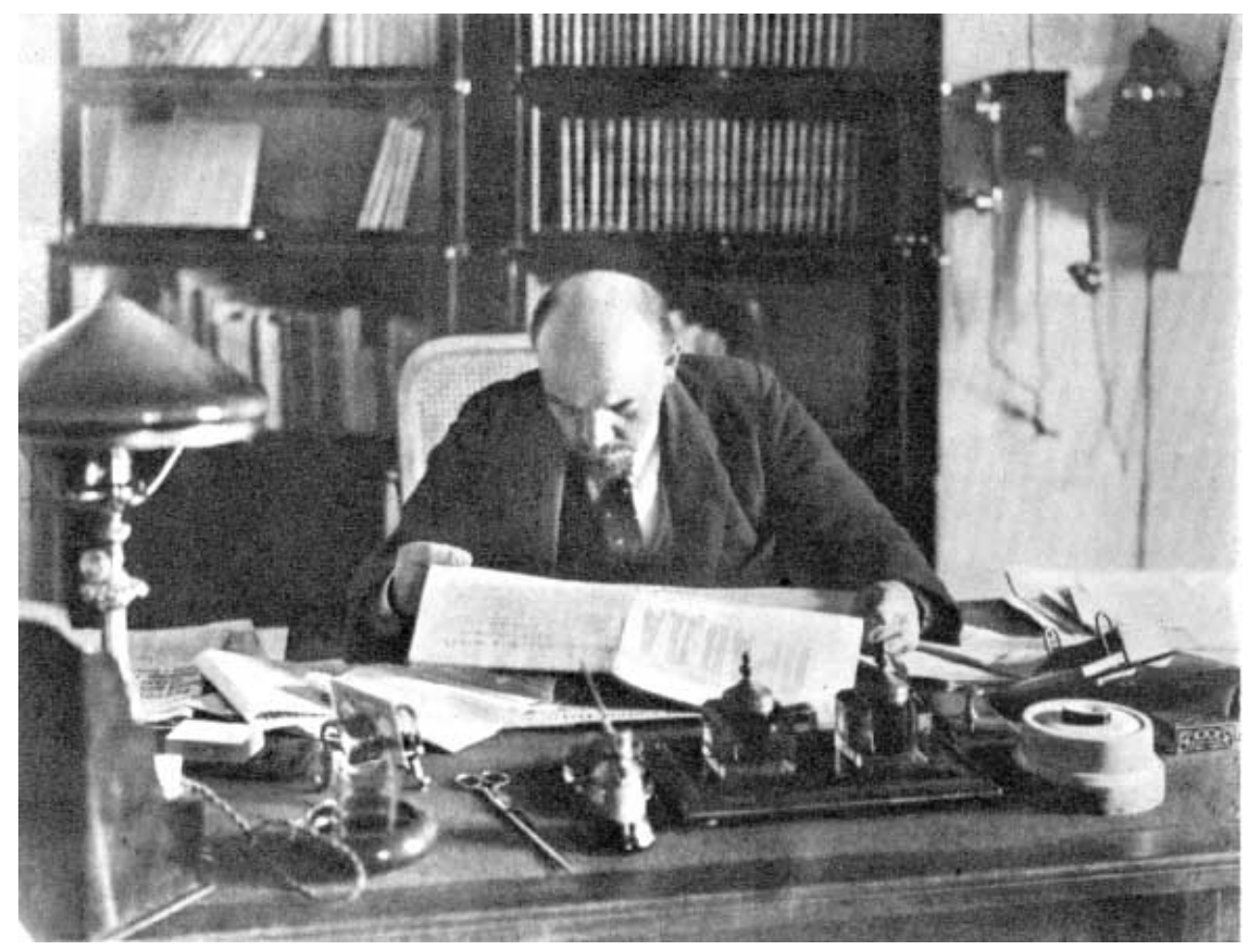

The two pictures themselves demonstrate the contrast between two ways of being; the sensual life of the physical and beautiful that gave Kschessinskaya meaning, and the intensity of the intellectual and political pursuits that absorbed Lenin. Having noted this contrast and the difficulty of reconciling these world views, it is worth noting that the second picture, Lenin reading a newspaper in his study, was taken in Kschessinskaya's house.

The villa that Nicholas II had given Kschessinskaya was handily located for the institutions of power in St. Petersburg, and so was occupied by the Bolsheviks as a convenient landing stage for nearby Admiralty Square. They simply arrived one day and demanded access. Kschessinskaya herself was shocked at the appropriation of her property, and eventually (after rescuing as many jewels and furs as she could) fled to France, eventually to Paris. Lenin, for his part, worked from her parlour in her absence, gave speeches from her balcony and to this day the house is preserved as a political museum. ${ }^{3}$

Kschessinskaya and Lenin were near contemporaries, and their relative fates and impact on their times are matters of history. Neither of their fates turned out the way they might have planned them, or could possibly have been foreseen just a few years earlier, but the intersection of their lives through Nicholas Il's generosity were important for ballet and for the identity of the Revolution. If Lenin was convinced of the triviality of ballet, occupying

\footnotetext{
${ }^{3}$ Lenin's biographers often cite his brother's execution by the Tsarist government in 1886 as the pivotal moment of his conversion to the cause of revolution, and it is hard not to suggest a moment of satisfying familial triumph of the Ulyanovs over the Romanovs. He couldn't possibly have reconciled a royal residence, but the home of the mistress to the Romanovs might have been other story. It should be noted that Kschessinskaya's salon has been restored since the collapse of the USSR, but Lenin's study arrangements remain.
} 
Kschessinskaya's house ought to have made him ponder about its power but his was an intellectual life, not a corporeal one.

\section{The Russian Ballet}

It is worth remembering that at the time of the Revolution all ballet, wherever it was performed, was referred to as Russian Ballet. The migration of court dancing in Versailles to the Francophile Russians across the nineteenth century left them as the custodians of its form, and they spent much of the second half of that century innovating and improving the notion of dance as a spectacle. At the time of the Revolution, the Ballets Russes had been touring Europe for fifteen years. It had been established from dancers provided by the Imperial Theatres in St. Petersburg and their repertoire (though the Ballets Russes extended this significantly, especially through the work of Michel Fokine). The chaos of the Revolution decimated the Marijinsky Theatre, with droves of dancers seeking sanctuary in the West, either with Diaghilev or the other minor troupes that sprung up from time to time. This left ballet in Russia itself in crisis.

Russian Ballet, whilst presented in St. Petersburg as the refinement of elegant Francophile physicality, was adored by Paris as the outpourings of the exotic East. Its most popular offerings were ballets like Scheherazade (1910) or Petrushka (1911), rather than the three act classics of the Marijinsky's repertoire. ${ }^{4}$ As a result of the departure of Petrograd-based dancers to Diaghilev, the Bolshoi in Moscow (still administered as part of the same organisation as the Marijinsky), acquired more prominence as the showcase for Russian Ballet. This shift of power was accompanied by the eventual movement of the capital back to its ancient home in Muscovy. There was a new government to satisfy if it were to maintain any presence at all.

We know the Bolsheviks saw culture as a potent weapon in their plans to change the world, and should remind ourselves of their original assumption that revolution in Russia would naturally lead to revolution elsewhere (especially Germany). As a result, their mobilisation of all parts of society in the cause of a workers' revolution included preserving and exploiting the arts. Anatole Lunarcharsky (1875-1933) may well have saved the arts from his more revolutionary minded colleagues but, as Fitzpatrick (1992) has pointed out, he did not do so on aesthetic grounds. Rather there were political considerations about the association of the Bolsheviks with quality cultural experiences that were often intentionally radical and transformative, like constructivist architecture and design, or films valorising the achievements of the masses in achieving societal change, like Eisenstein's films Strike (1925) or October (1927). The transition was comparatively easy for the Bolshoi Opera, in reviving work banned under the Tsar (The Decembrists) or commissioning work that focussed on vast, sweeping choruses that utilised mass movement and singing (an operatic version of Battleship Potemkin was staged). The issue was about how ballet might fit into this picture of uncompromising newness. What would ballet for the Bolshveiks look like? There were plenty of dancers who wanted the ballet to reform and take part in the exciting new polity that was emerging, and plenty of others who felt that ballet was a comfort to those discombobulated by the social and political ructions around them. Going to the ballet proved stubbornly popular, (indeed a huge black market for tickets grew up) but still needed to contribute to the new polity on which it now depended for survival.

I have discussed elsewhere the travails of ballet in Soviet Russia during the 1920s (see Sporton, 2012 for more detail), but essentially the efforts of the Bolshoi in particular remained focussed on the political content of the narratives of new work. It is worth repeating at this point that no one knew exactly how the Revolution would play out in terms of the

\footnotetext{
${ }^{4}$ Indeed, the 1924 production of Sleeping Beauty almost sank the company completely as there was no audience in the West for such placid stuff.
} 
international changes that were expected to flow from the events in Russia, and even during the Civil War that followed, it was clear some powerful forces had been unleashed.

Throughout the twenties, in all art forms, there were vigorous attempts to reinvent content in a guise consistent with the aims of the Bolsheviks, especially as they concluded the Civil War and took a grasp on the nation. As we know, this doomed many of those involved in these experiments as the Great Terror took hold a decade later, but the radical faction at the Bolshoi, led by the choreographer Goliezovsky, took their responsibilities to the Revolution seriously. They mounted a number of failed ballets that attempted to subvert the traditions of ballet and reinvent them as socialist representations. The Footballer,(1930) had just a handful of performances, and it seems striking in contrast to the Swan Lake productions that preceded it. Gone are restrictive costumes and princely behaviour: the heroes of this scenario were honest workers, trying to outwit NEPmen and the black market, dressed in stage versions of modern dress. Other ballets during this period might have large sums spent on production and rehearsal (Teolinda, 1925, or Smerch, 1927), and see few performances or none at all, given the potentially controversial content they were unwittingly generating by directly addressing Soviet themes.

The risks involved were unknown for all parties, but there is no question of the sincerity of the solutions the artists were seeking. They were political first, with a focus on scenarios that would tell the right story about the emergent New Society. In other words, they were seeking to convince Lenin and his successors of their value through the very aspects from which the contempt of ballet as culture was derived. This was, essentially, a type of cultural warfare between those making it and those with control of it. Whilst this solution more or less worked for art forms like film, the theatrical storytelling of ballet remained waiting for the validation of its efforts by the political and cultural elite. As long as it persisted in making claim to the stories of Soviet life, it appeared doomed to failure. Goliezovsky's notion of the 'dram-balet' contained within it only an insurmountable challenge to those who would not grant ballet the same capacity as film or opera to spell out stories sufficiently didactically in order to be unambiguous.

Of course, this was approaching the problem from the wrong direction. This is not to justify the abominable treatment of a generation of dancers and choreographers, but to understand what was ultimately necessary for ballet to become the cultural face of the Soviet Union. As indicated above, Lenin's contempt for it as an art form was surely its superficiality and theatricality. These could hardly have created or reflected the serious cast of mind required of the Soviet citizen engaging with culture. The ballet community, by misreading the problem, was retaining what was for the Soviet cultural authorities the worst component of the art form, that the stylisation of ballet as drama required the incredulous, and this wouldn't wash in explaining the regime to the public. What was required was to shift in another direction entirely.

As the cultural policy guru John Pick (1981) observed in a visit to the Soviet Union in the seventies, the art forms that tended to be favoured by the Soviet regime were inclined to be ones without ascribable meaning. Practices like circus, classical music or ballet were ultimately popular with ministers of culture precisely because of the absence of correspondence between action, experience of them and specific analogues of thought. This insight partly explains the shortcomings of the early Soviet period, where the performance of ballet itself was treated as secondary to the demands of the storytelling. It was the storytelling itself that contained the danger, and this is also clear from the critical assessments of the Soviet censors. Even the otherwise obsequious Tikhomirov, later to become the Bolshoi director, was nearly fired for The Red Poppy (1927), a mawkish, sentimental ballet about the oppression of Chinese peasants (it was revived for an unlikely visit to the Bolshoi of Mao Tse Dong in 1950). 
Whilst there is plenty of support for the idea that after the early 1930s and the abandonment of didactic Soviet themes ballet in Russia avoided the political issues of culture by reverting to a traditional repertoire, and this must at least be partly true, I want to offer up an alternative explanation, linked to the examples I have offered at the beginning of this essay. Cultural practice in Tsarist times required an elite (and moneyed) audience. It also produced a disproportionate number of artists in many fields for a nation assumed in the West to be culturally backward, including the export of some of its treasures to Paris, Berlin, London and the rest. The structure of Russian society before the Revolution brought forth brilliant novelists and uncompromising visual artists (Marks, 2003), as well as an art form called Russian Ballet and composers that were hugely influential in the West. This was as much to do with an environment where the elite level of society was seeking distance between it and the source of its wealth (generally, the labour of peasants), though the work that emerged was not short of cross-referencing that world, as anyone familiar with Tchaikovsky's borrowings of folk song, Malevich's representations of peasant life or Tolstoy's descriptions of their labour can attest. The arts became a high-culture prism used to express something of a society preoccupied with its notion of backwardness and yearning for cultural respect. This was not uncontroversial, but also not unnoticed by those seeking to remake that society. The arts had the power to persuade. This might make them dangerous or useful or even both. The ballet of the Imperial Theatres was organised to reinforce the legitimacy of the Tsar (and the late nineteenth century repertoire is littered with examples of this), and to do so in a way little different to the symbolism and metaphorical ballets of the French court of the early eighteenth century. The Bolsheviks could surely only fear the implications of their own representation on the ballet stage in contrast. It could only be inconsistent with a notion of equality and of the creation of the worker's state, or portray them without the poise and glamour of their predecessors.

The solution is often dismissed in the West as a cop-out, but it ought to be taken much more seriously than that. Ballet began to reflect to its audiences a key Soviet value: hard, physical work undertaken on behalf of others. Its presentation went well beyond the Tsarist notion of pretty femininity represented by Kschesskinskaya and her voluptuous sensuality and towards the dancer as cultural worker. The codes and techniques of ballet suppressed the potential of eroticism, however scantily clad the dancers may have been. They were offered less as sexual objects as models of physical perfection possible only through the Soviet system. The closed, smoothed and perfected form of the body that Bakhtin (1984) would theorise as its evolution saw its apotheosis in the white leotards, long legs and pink tights of the dancers in Les Sylphides or Swan Lake ahead of dramatic portrayals of difficult to communicate narratives. It was technical capacity that trumped other aspects of the presentation of the Soviet body, affirming as it did the rightness of a system that could produce such seemingly effortless perfection. By concentrating on the technical abilities of their artists, investing in their physicality and turning their energies in this direction, rather than abstract notions about creative expression, the Soviet Union found a new means of presenting itself in cultural form. In a conflict between symbolic concept and practical manifestation, it was the practice that triumphed. 


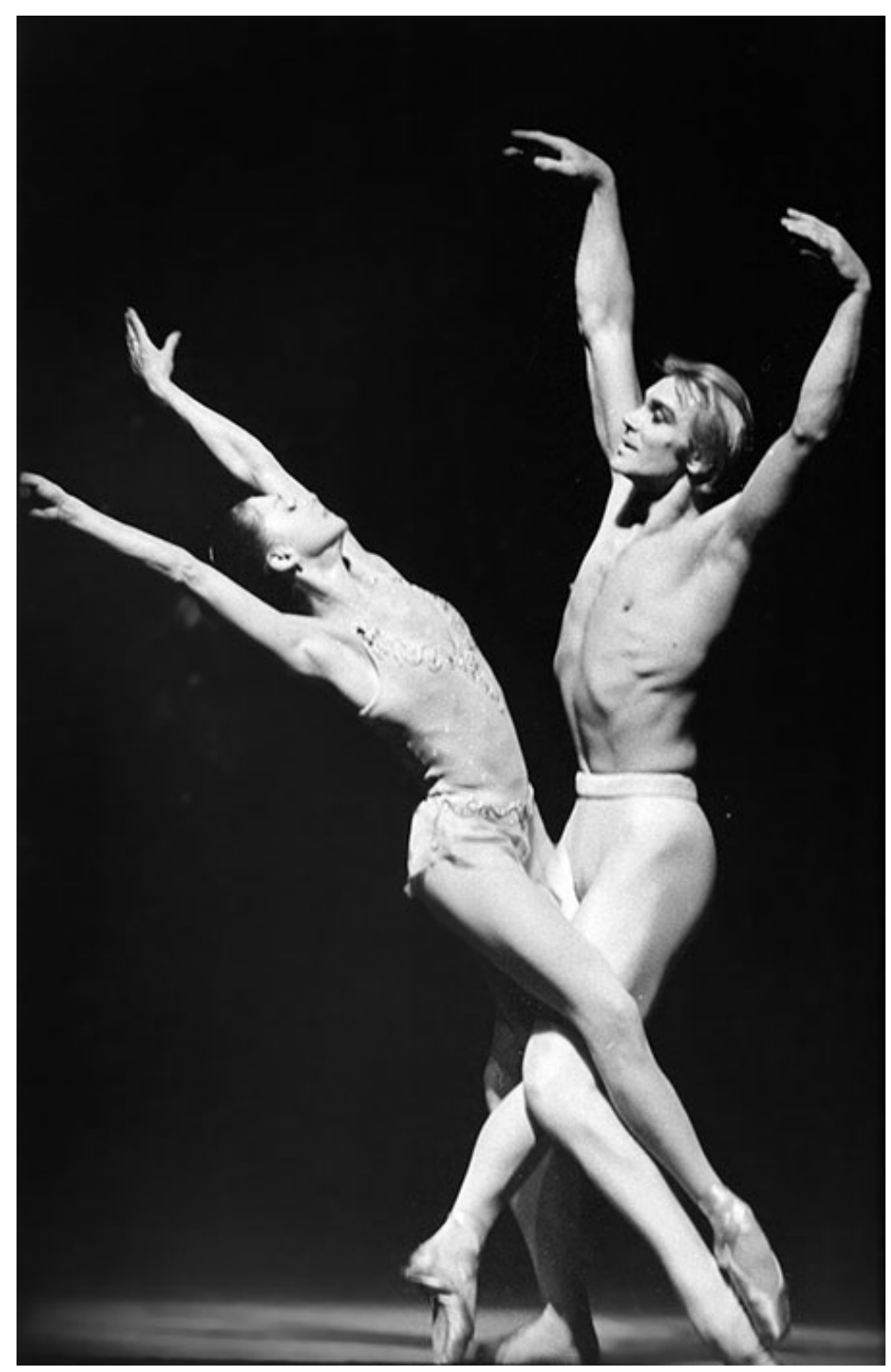

Most curiously, the exploration of this aspect of Soviet ballet has often attracted scorn. For many, it represented the withering of Russian ballet traditions into the safety of practical mastery. This assumes that ballet ought to have been driven by the same exigencies wherever it was practiced, though it is also quite possible to identify the issues I have discussed in the work of George Balanchine, so not quite so far removed as all that from wider trends. What is more interesting here is not the shift away from story telling (these were only ever an excuse for staging divertissement in any case). It is the recasting of the work of ballet, seeing it as consistent with the demands on everyone to commit their labour to the glory of the state. That this appears to have reduced the political heat around ballet is obvious, but in this interpretation, it is the clumsy, ham-fisted attempts at overt political statement that look like the exception. The emphasis on technical excellence became, effectively, the only way forward for Russian ballet, the energy of the dancers finding acceptable expression in physical capacity. This was certainly a form of freedom, and there is no credible way of suggesting the Bolshoi or any other Russian ballet company, as harbouring a fifth column because of it. In fact, as recorded in the minutes of any number of meetings of the company during Soviet times, dancers and artistic staff were strong supporters of the state that had offered them patronage, and were concerned to make international tours, for example, a success as Soviet exports. More obviously, it was the means of creating apolitical space, an uncontroversial opportunity to excel without compromise whilst remaining true to the spirit of the nation that appears to have inspired 
them. More than that, it was through this exemplification of Soviet possibility that ballet grew to be the definitive cultural form of the USSR. All the way to the end of the regime, they still showed Swan Lake on television in advance of a major announcement or the death of a leader. This only happens if everyone understands the significance of this form of labour as exceptional.

This changes to a great extent our perception of what ballet might mean in the context of the Soviet Union, but also stands as a rebuke to those who believe the validation of cultural practice trumps the practice itself. The mastery of technique, it appears, was the very route to the freedom to express for the Soviet citizen. The Soviet dancer took part in their labour with no less vigour than expected of other citizens, Stakhanovites every one, and whilst their physical exertions may have been of exceptional finesse, they were still obviously, almost ostentatiously, hard; physical rather than erotic and disciplined rather than spontaneous. Ballet was far better at reflecting a political reality than shaping one.

The significance of this ought not to be elided in the efforts to colour the Soviet Union as dominated by an uncreative bureaucracy imposing its will on artists to the detriment of their development. The priorities of Soviet ballet were not the glory of choreographers (a group that clearly suffered if they flirted with Soviet themes), but the performances of dancers in their demonstration of Soviet values. Those values (and those dancers) reflected a desire to reward merit in the technical sense. The preoccupation with dragging what the new leaders believed to be a backward country into technological future was played out in all areas of Soviet life. The work of dancer was hardly different, and there is plenty of consensus about the huge improvements in technique that emerged from Soviet times. To miss the significance of this by locating its cause in a fear of creativity or recriminations about creativity could only be partly true. When Stalin described artists as 'engineers of human souls', his metaphor was only partial, reflecting a Soviet fixation on the practical value of engineering to the development of the new society.

\section{References}

'Balet T-4' (n.d.), Reviews, Moscow: Bolshoi Theatre Archives.

Bakhrushin, Y.A. (1977), History of Russian Ballet, Moscow: Prosveshenie.

Bakhtin, M.M. (1984), Rabelais and his World, Bloomington, Ind.: Indiana University Press.

Berlin, I. and Hardy, H. (2004), The Soviet Mind: Russian Culture Under Communism, Washington

DC: Brookings Institution Press.

Bourdieu, P. (1994), The Field of Cultural Production, New York: Columbia University Press.

Caute, D. (2003), The Dancer Defects, Oxford: Oxford University Press.

Chernova, N. (1984), Kasyan Goleizovski: zhizn' i tvorchestvo stat'i, vospomin-aniia, dokumenty/ Kasyan Goleizovski: Life and creativity in articles, memoirs and documents, Moscow: Vserossiiskoe teatral'noe obshchestvo.

Demidov, A. (1985), Lebedinoe Ozero/Swan Lake, Moscow: Isskustvo.

Federov, V.V. (1958), Repertoire of the Bolshoi Theatre, 1776-1955, Moscow: Government Musical Publishing House.

Erazhi, C. (2012), Swans of the Kremlin: Ballet and Power in the Soviet Union, Pittsburgh, USA:

University of Pittsburgh Press.

Fizpatrick, S. (1992), The Cultural Front, New York: Cornell University Press.

Grigorovich, Y. (ed.) (1981), Ballet Encyclopaedia, Moscow: Soviet Encyclopaedia.

Homans, J. (2010) Apollo's Angels: A History of Ballet, London: Granta Books.

Lenin, V.I. (1976), Lenin: Collected Works, Moscow: Progress Publishers.

Pick, J. (1980), Off Gorky Street: Arts Administration in the USSR, London: John Offord Publications.

Morrison, S. (2016), Bolshoi Confidential, New York: W.W. Norton \& Co.

Roslavleva, N. (1966), Era of the Russian Ballet, London: Victor Gollancz.

Slonimsky, Y. (1947), The Soviet Ballet, New York: Philosophical Library. (1956), The Bolshoi Theatre Ballet, Moscow: Foreign Languages Publishing House.

Souritz, E. (1990), Soviet Choreographers in the 1920s, London: Dance Books. 
Sporton, G. (2008), 'Power as Nostalgia: The Bolshoi Ballet in the New Russia', in D. Barnett and A. Skelton (eds), Theatre and Performance in Eastern Europe: The Changing Scene, Lanham, MD: Scarecrow Press, pp. 3-12.

(2013), "The Conservative Revolution: the Bolshoi Archives", Scene, Vol. 1., No. 1, Jan, 2013, pp.85-98.

Zarubin, V.I. (1998), Bolshoi Theatre Ballet Premieres on the Russian Stage, 1825-1997, Moscow: Ellis Lak.

Zorkii, V. (2005), 'Big Changes', Bolshoi Gorod, Moscow, pp. 16-17. 